\title{
Hyperglycosylated gp120 mutants elicit improved CD4-binding site directed antibodies in a heterologous prime:boost regimen
}

\author{
FK Ahmed $^{1 *}$, BE Clark ${ }^{2}$, R Pantophlet ${ }^{1}$ \\ From AIDS Vaccine 2012 \\ Boston, MA, USA. 9-12 September 2012
}

\section{Background}

The CD4-binding site (CD4bs) on gp120 is targeted by broadly neutralizing antibodies (nAbs) and is therefore of interest for vaccine design. Insight derived from molecular interactions of CD4bs-specific antibodies with gp120 has guided structure-based protein design and the development of a number of immunogens. Of equal interest are strategies to improve potency and durability of desired $\mathrm{nAb}$ responses to such immunogens.

\section{Methods}

We generated truncated, hyperglycosylated gp120 mutants designed to selectively present $\mathrm{nAb}$ epitopes overlapping the CD4bs. To help focus antibody responses to these epitopes, we conducted a heterologous prime:boost immunization using two mutants (termed $\triangle \mathrm{N} 2 \mathrm{mCHO}$ and $\triangle \mathrm{N} 2 \mathrm{mCHO}(\mathrm{Q} 105 \mathrm{~N}))$ in combination with a resurfaced gp120 core protein (RSC3) that preferentially presents the CD4bs neutralizing face. Groups of animals were primed with $\triangle \mathrm{N} 2 \mathrm{mCHO}$, unappended or $\mathrm{N}$-terminally appended with one of three immunostimulatory sequences known to amplify humoral responses - PADRE, N10 or C3d. The animals were boosted with RSC3 and then $\triangle \mathrm{N} 2 \mathrm{mCHO}$ (Q105N). Serum specificities were dissected using CD4bs and non-CD4bs mAbs and responses were followed at the cellular level by phenotyping the memory B cell compartment after each injection.

\section{Results}

Relative to other groups, PADRE- $\Delta \mathrm{N} 2 \mathrm{mCHO}$ elicited significantly more rapid and higher titres against gp120 and the immunogens, suggesting that PADRE has superior immunoactivating properties. The PADRE- antibodies also bound greatest to epitopes overlapping the CD4bs. Unexpectedly, only sera from N10- animals exhibited significant neutralizing activity against select tier $1 \mathrm{~B}$ and 2 viruses. Unanticipatedly also, no significant differences were observed at the memory B cell level between the groups for gp120 specificity.

\section{Conclusion}

Our results show that selective exposure of conserved epitopes through the use of varied immunogens fused with immunostimulatory sequences, in particular PADRE, can boost desired antibody responses. Together, our data highlight the importance of not only immunogen design but also formulation on directing antibody responses to conserved epitopes.

\author{
Author details \\ 'Simon Fraser University, New Westminster, Canada. ${ }^{2}$ StemCell Technologies, \\ Vancouver, Canada. \\ Published: 13 September 2012 \\ doi:10.1186/1742-4690-9-S2-P73 \\ Cite this article as: Ahmed et al:: Hyperglycosylated gp120 mutants \\ elicit improved CD4-binding site directed antibodies in a heterologous \\ prime:boost regimen. Retrovirology 2012 9(Suppl 2):P73.
}

${ }^{1}$ Simon Fraser University, New Westminster, Canada

Full list of author information is available at the end of the article

(c) 2012 Ahmed et al; licensee BioMed Central Ltd. This is an Open Access article distributed under the terms of the Creative Commons Attribution License (http://creativecommons.org/licenses/by/2.0), which permits unrestricted use, distribution, and reproduction in any medium, provided the original work is properly cited. 